\title{
Asymmetric Information and Bargaining Delays
}

\author{
Chang-Kon Choi ${ }^{1^{*}}$ \\ ${ }^{1}$ Department of Economics, Chonbuk National University \\ 비대칭적 정보와 협상지연 \\ 최창곤 ${ }^{1 *}$ \\ ${ }^{1}$ 전북대학교 경제학부
}

\begin{abstract}
Applying Markov Stochastic Process theory, this paper attempts to suggest a tentative model explaining how private information may cause bargaining delay. It is shown that the bargaining delay is critically dependent on the specification of information. It turns out that the delay tends to be longer in bargaining where information is imperfect. This means that bargaining models frequently can have an infinite delay under imperfect information while they have finite delay of bargaining before reaching the agreements if information is perfect. Other interesting result is that bargaining delay may depend on who makes the offer first. And it is also shown that bargaining tends to end earlier if both players (seller and buyer) can make offers in turn than the case where only one side make a offer.
\end{abstract}

Key Words : Asymmetric information, Private Information, Duration of bargaining

요 약 협상과정을 Markov 확률과정으로 전제하고 확률과정의 상태별 이행확률의 크기가 협상참가자의 사적인 정 보에 의하여 결정된다고 가정한다. 예를 들어, 판매자와 구매자의 가격협상의 예에서 협상상대방의 특징-예를 들어, 유보가격- 에 대한 정보가 사적인 정보일 때 협상참가자 모두가 수용가능한 가격을 찾는 과정이 이행확률의 크기에 영향을 받고, 결과적으로 협상지연의 정도를 결정함을 보인다. 또한 협상의 참가자가 모두 교대로 제안을 하는 제안 과 대응제안의 방법의 협상에서보다 협상참가자중 어느 한 쪽의 일방에서 제안을 하는 방법의 협상에서 협상지연이 더욱 길어짐을 보인다.

\section{Introduction}

This paper aims to suggest a tentative model of bargaining delay, in which there exists private information. It is not new that private information may be a barrier to efficient bargaining agreement. This paper is an attempt to analyze the problem of bargaining delay in different way from current other studies which use hazard rate, in particular, like the studies of strike duration. For example, see Heckman[8], Crampton[3], and more recently Vidual[21]. While talking about bargaining, thus, this paper does not discuss the typical issues in the studies of bargaining, like the existence, uniqueness or stability of equilibrium, etc.. We approach the issue in practical sense.

As a model to solve economic problem, the noncooperative or sequential bargaining theory has been discussed extensively for past several decades. It is shown that the noncooperative bargaining model can have a unique and stable solution under plausible or compelling assumptions. See Osborne and Rubinstein[15], Admatti and Perry[1], Mutto[13,14] for a good summary of

This paper was supported by research funds of Chonbuk National University in 2012.

${ }^{*}$ Corresponding Author: Choi, Chang kon(Chonbuk National Univ.)

Tel: +82-10-2918-3045 email: ckchoi@jbnu.ac.kr

Received January 11, $2013 \quad$ Revised (1st March 19, 2013, 2nd April 10, 2013)

Accepted April 11, 2013 
bargaining literatures. Binmore and Vulkan[2] is one recent example showing how the game theory can be applied to the bargaining situation.

However, surprisingly enough, there has not been much discussion about the problem of how long bargainers should bargain to arrive their unique and stable solution. Thus, most studies have been ignoring the observation that in the real economy, the costly delay of bargaining might be more important thing than the solution itself. When bargaining is over in the real economy, there is always a solution in some sense without regard to whether it is acceptable to both sides of bargaining or not. The point is here, that in the real economy, the more important question is not what players agree in a bargaining game, but how long they should bargain to get the agreement. Among the bargaining literatures, Kennan and Wilson[10] summarizes three models of bargaining delay and private information. They conclude that the existing bargaining models can not explain the real bargaining procedure and delay issues. Crampton[3] shows that delay could be strategic. Feinberg and Skrzypacz[6] look at the effect of second order uncertainty on the delay in the bargaining. Vidual[21] is a recent paper dealing with the delay issue.

Unlike the previous studies, however, this paper takes a different approach so that it focus on the dynamic characteristics of bargaining procedure. More specifically, this paper describes the bargaining as a three state Markov process to look at the dynamic feature of bargaining procedure. Once bargaining procedure is described by Markov process, one can apply the so called the first step analysis in measuring the length of duration. It is also assumed that the information is asymmetric in the sense that the agent of one side has no correct information about that of other side.

The result of this paper shows that the bargaining delay is possible because of the asymmetric information. The duration of bargaining disagreement may be longer due to the lack of correct information about bargaining partner, for example the reservation price. This result is consistent with the fact that bargaining models frequently can have an infinite delay under imperfect information while they have finite delay before reaching the agreements if information is perfect. This is a similar observation to the theoretical results that bargaining model tends to have difficulty to have unique equilibrium with imperfect information. Other interesting result is that bargaining delays may depend on who makes the offer. It is shown that bargaining tends to delay longer if only one side (seller or buyer) can make offers than the case where both sides make offers in turn.

This paper is developed as follows. In section II, a simple bargaining problem is set and we see that bargaining delay is not a problem if we have perfect information about each agent's preference including reservation price. It means that we have a finite duration of bargaining procedure under plausible assumptions. However, imperfect information in section III will introduce problem in bargaining as far as the time required for agreement is concerned. And we will see the differences in duration which one-sided and two-sided information make. In section IV, final conclusion closes the paper

\section{Asymmetric Information and Bargaining Delay}

\section{II.1 A Bargaining Problem}

To begin with, consider a typical bargaining problem where a seller and a buyer are bargaining over the price of an object. Or another example may be a bargaining between two players over partition of a cake. While there are many bargaining example, as far as bargaining delay is concerned, the most interesting one may be bargaining between a firm (= buyer of labor service) and its union (= seller of labor service) over negotiation of wage or partition of a cake of size. The cake could be a residual after paying off all costs at the end of accounting year. While the argument in the below are proceeded as a bargaining problem of seller and buyer over the price of a good, it can be equally applied to other bargaining situation.

Each bargainer is assumed to keep in mind one constant reservation price: let's call $\boldsymbol{S}$ for seller and $\boldsymbol{B}$ for buyer. Thus, $\boldsymbol{S}$ is the minimum price which seller wants to receive from buyer, and $\boldsymbol{B}$ is the maximum price which buyer wants to pay for this good. So, for example, $\boldsymbol{B}$ may be the wage firm may pay while $S$ the reservation 
wage for its union. For bargaining to occur, it should be trivially true that $\boldsymbol{S}<\boldsymbol{B}$. For any offer to be accepted by both players, it should be in $[\boldsymbol{S}, \boldsymbol{B}]$. The probability of reaching an agreement is the probability that each player's offer is in the range $[S, B]$, i.e., which is joint event that both seller and buyer's offer is between $\mathrm{S}$ and $\mathrm{B}$. The other contents in bargaining model are referred to other bargaining literatures, like Osborne, Martin and Rubistein[15], Muthoo[14] since our goal is not to analyze a particular bargaining problem.

Now it is assumed that this bargaining procedure can be described by a Markov stochastic process $\left\{\boldsymbol{Z}_{i}(\boldsymbol{t})\right\}$ in which the states are following. (here, $i$ denotes state- 1 , 2, 3 - and $\boldsymbol{t}$ denotes time)

$$
\begin{aligned}
& Z_{1}=\text { event that the value of offer is in }(0, \mathrm{~S}) \\
& Z_{2}=\text { event that the value of offer is in }(\mathrm{S}, \mathrm{B}) \\
& Z_{3}=\text { event that the value of offer is in }(\mathrm{B}, 1)
\end{aligned}
$$

where notation for time is omitted. Then, the transition probability matrix can be written as follows,

[Table 1] Transition probability matrix

\begin{tabular}{c|c|c|c}
\hline State & 1 & 2 & 3 \\
\hline \hline 1 & $P_{11}$ & $P_{12}$ & $P_{13}$ \\
\hline 2 & $P_{21}$ & $P_{22}$ & $P_{23}$ \\
\hline 3 & $P_{31}$ & $P_{32}$ & $P_{33}$ \\
\hline
\end{tabular}

where $\boldsymbol{P}_{i j}$ means the probability of moving from state $\boldsymbol{i}$ to state $\boldsymbol{j}$, and it is function of exogenous variables.

\section{II.2 Information and Bargaining Delay}

When information is perfect so that each player knows other player's reservation price, the bargaining may end immediately: the solution would be $\frac{\left(1-\delta_{B}\right)}{\left(1-\delta_{S}\right)\left(1-\delta_{B}\right)}(B-S) \quad$ or $\quad \frac{\left(1-\delta_{S}\right)}{\left(1-\delta_{S}\right)\left(1-\delta_{B}\right)}(B-S)$ depending on who is the first mover. Here, $\delta_{s}$ and $\delta_{B}$ are discount factors for seller and buyer respectively. In a simple bargaining problem over the price of an object, the duration of bargaining tends to be very short and be one shot game when the information is perfect. The perfect information is a very unrealistic assumption which does not hold in the real bargaining problem.

If we specify more realistic aspects about the information set of each bargainer, the duration of bargaining procedure may not be so short. Since bargaining delay matters under imperfect information, here, we introduce bargaining problem without perfect information.

To begin, drawing a simple model where buyer and seller offer a price in turn, Or an arbitrator can make offer to both players without knowing their reservation prices. If seller makes an offer first, for example, the bargaining procedure looks like following. The asking price seller may offer may be in one of two ranges of $[\boldsymbol{S}, \boldsymbol{B}]$ or $[\boldsymbol{B}$, 1], the states of which are denoted $Z_{2}(t)$ and $Z_{3}(t)$ respectively. Then, buyer could accept or reject to each offer, depending on the state of bargaining. It is obvious that buyer would be willing to accept the offer only if the state is $Z_{2}(t)$. If buyer accepts the offer, bargaining ends. When the bargaining state is $Z_{3}(t)$, buyer rejects the seller's offer and offers another bid price (which should be less than B).

In this bargaining, we have following transition probability matrix since they do not have any information about the partner's reservation price, which means that there is a high probability for offers to be in an unacceptable range.

[Table 2] Transition probability with Asymmetric information

\begin{tabular}{c|c|c|c}
\hline State & 1 & 2 & 3 \\
\hline \hline 1 & 0 & $P_{12}$ & $P_{13}$ \\
\hline 2 & 0 & 1 & 0 \\
\hline 3 & $P_{31}$ & $P_{32}$ & 0 \\
\hline
\end{tabular}

where the zero probability of $P_{11}$ is saying that seller increases his offer above his reservation price after he rejects buyer's offer below it, and the zero chance of $P_{31}$ is saying the same for the buyer's strategy. And state 2 is absorbing state in which both bargainers are ready to accept partner's offer in this range, which is rational. To solve the expected duration for this bargaining to be in one of transient states 1 and 3 , we make one simultaneous 
equation system which may be solved into it. Let $W_{i}^{1}$ denote the expected duration for this bargaining to stay in state 1 with initial state $i$. The expected delay of bargaining for each initial state is given as following. See Taylor and Karlin[20] for this exercise.

$$
W_{1}^{1}=\frac{1}{1-P_{13} P_{31}}, \quad W_{3}^{1}=\frac{P_{31}}{1-P_{13} P_{31}}
$$

Simulating these expressions, following three figures show how duration varies with the values of transitional probabilities. For a convenience, the value of $P_{31}$ is specified as $0.3,0.5$ and 0.7 .

Now let $W_{i}^{3}$ denote the expected duration for this bargaining to stay in state 3 with initial state $\boldsymbol{i}$ :

$$
W_{1}^{3}=\frac{P_{13}}{1-P_{13} P_{31}} \quad W_{3}^{3}=\frac{1}{1-P_{13} P_{31}}
$$

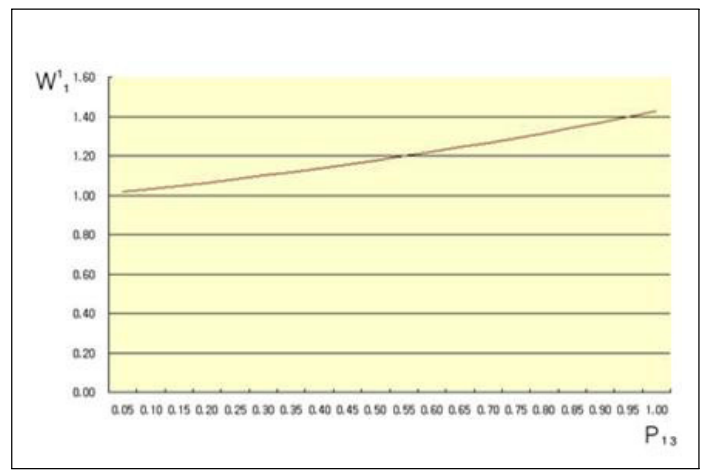

[Figure 1] Expected delay with $P_{31}=0.3$

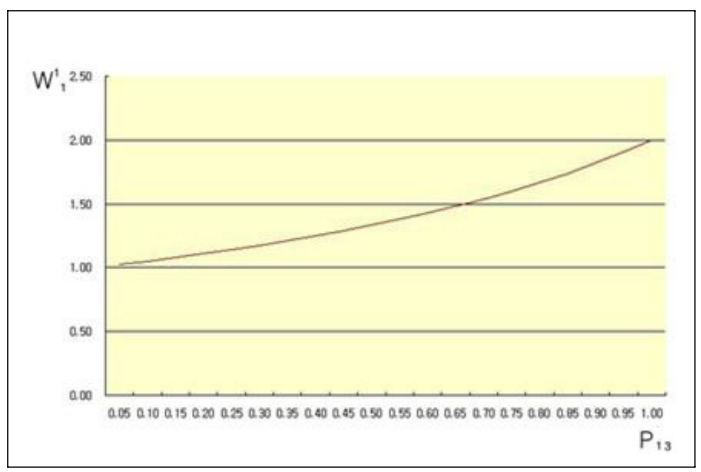

[Figure 2] Expected delay with $P_{31}=0.5$

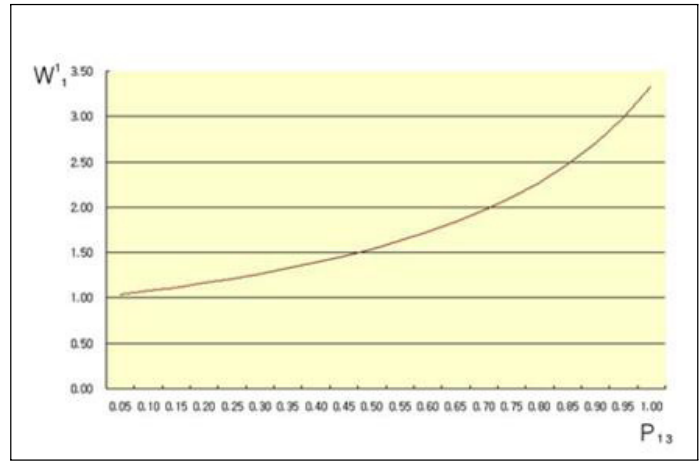

[Figure 3] Expected delay with $P_{31}=0.7$

The durations, $W_{i}^{1}$ in (1) and $W_{i}^{3}$ in (2) are showing a high chance of infinite bargaining duration if $P_{13} P_{31}$ approaches to 1 . It also says while finite duration may be possible, but the duration might be long and certainly more than one period. This means that it is possible to have the infinitely continuous disagreement if each player is offering price which is only favorable to himself with no information about partner's reservation price. Thus, as $P_{13}$ or $P_{31}$ get bigger, the duration in this game gets longer than that in the perfect information case. And since $W_{1}^{1}>W_{3}^{1}$, it means that the bargaining tends to stay more in state 1 when buyer is the first player to make offer (so initial state is state 1) than when seller is the first player. Or since $W_{1}^{1}>W_{1}^{3}$, it means that once the bargaining started in state 1 , there is more chance for it to delay in state 1 than in state 3 , vice versa. A proposition summarizing the above discussion so far is useful.

Proposition 1: In a bargaining problem over the price of an object, when the information is imperfect, the expected duration of bargaining procedure given by (1) or (2), and tends to be very long.

Now it is shown that the bargaining delay becomes longer if only one side (buyer or seller) makes an offer. To begin, we assume that only seller makes an offer each time and the buyer has option of accepting or rejecting it. If the latter accepts the offer, the bargaining is over. However, if he rejects it, he should wait for next offer. In this simple model of bargaining, we can presume that 
seller has no incentive to offer a price below seller's reservation price and buyer has no incentive to reject an offer above it and below his reservation price. Reflecting this fact, we have one very simple transition matrix as following,

[Table 3] Transition probability when only seller offers]

\begin{tabular}{c|c|c|c}
\hline State & $\mathbf{1}$ & 2 & 3 \\
\hline \hline $\boldsymbol{1}$ & 1 & $\boldsymbol{0}$ & $\boldsymbol{0}$ \\
\hline $\mathbf{2}$ & 0 & $\boldsymbol{1}$ & $\boldsymbol{0}$ \\
\hline $\mathbf{3}$ & 0 & $\boldsymbol{P}_{32}$ & $\boldsymbol{P}_{33}$ \\
\hline
\end{tabular}

Thus, this process has two absorbing states of 1 and 2 , and one transient state of 3. To measure the expected duration in state 3 , again, we apply the above simple analysis of probability theory. Then, we get one system of equations where $W_{i}^{3}$ denotes the duration for the bargaining to be in state 3 with initial state $\boldsymbol{i}$. By solving for $W_{i}^{3}$, we have

$$
W_{3}^{3}=\frac{1}{1-P_{33}}
$$

As seen in this solution of $W_{3}^{3}$, the duration of disagreement in bargaining can be long since there is no reason to expect the probability of $P_{33}$ to be 0 . As $P_{33}$ approaches to 1 , the duration becomes longer. Comparing (2) and (3), one can see the value in (3) is greater than that in (2), implying a longer delay of bargaining. Thus, we can see an intuitively interesting result that when both sides can make offers, the bargaining tends to end early. Comparing to [Figure 1], [Figure 4] confirms this results.

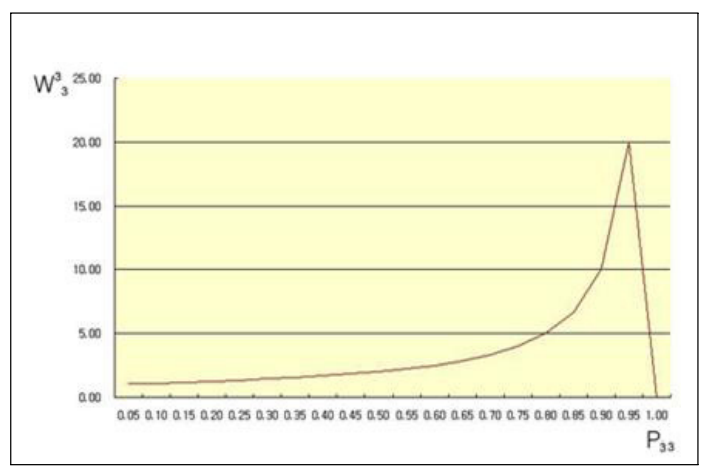

[Figure 4] Expected delay when only seller offers
Proposition 2: In a bargaining problem over the price of an object, when the information is asymmetric, the expected duration of disagreement in the bargaining may be shorter when both players make offer than when only one player does.

In sum, the Propositions 1 and 2 imply that when information structure is asymmetric, it may delay bargaining procedure. Describing the bargaining procedure as a three state Markov process, one can see that transitional probabilities between offers made by sellers and buyers are affected by the information structure. That is, the sooner the offers are made in the acceptable range of $[\boldsymbol{S}, \boldsymbol{B}]$, the sooner the bargaining ends. The probability of an offer by a player to be in the acceptable range of $[\boldsymbol{S}, \boldsymbol{B}]$, however, may be affected by information structure. It is obvious that many other things like time preference, disagreement costs, outside options also affect the bargaining procedure, among which this paper focus on asymmetric information about the bargaining partner's reservation price. For example, Manzini and Mariotti[11] looks at the implication of outside option on bargaining delay.

Under this kind of asymmetric information about the reservation prices of both players, thus, what matters is the probability of an offer to be put in the acceptable range of $[\boldsymbol{S}, \boldsymbol{B}]$. Without information on bargaining partner's reservation price, a bargainer needs to form an expectation about it. The seller, for example, must form the expectation about buyer's reservation price. Following the typical assumption about expectation-forming behavior, the seller is assumed to form the expected value of buyer's reservation price, $E\left[B^{s} \mid I_{t}^{s}\right]$ using all available information, in which $I_{t}^{s}$ is the seller's information set at time $t$. Based on this expected value, the seller's reasonable offers may be less than or equal to $E\left[B^{s} \mid I_{t}^{s}\right]$. Then, the bargaining delay is determined by the how close $E\left[B^{s} \mid I_{t}^{s}\right]$ is to the actual value of $B$. The transitional probability is affected negatively by the difference between the actual reservation price and the expected value by seller, which also determines the bargaining delay. 


$$
P_{12}=g\left(\left|B-E\left[B^{s} \mid I_{t}^{s}\right]\right|\right) \quad \text { with } g^{\prime}<0
$$

For the same token, the buyer should form the expectation about the seller's reservation wage. Like the case of buyer, the difference between $S$ and $E\left[S^{b} \mid I_{t}^{b}\right]$, due to the asymmetric information, affect the transitional probability, resulting in a bargaining delay.

$$
P_{32}=f\left(\left|S-E\left[S^{b} \mid I_{t}^{b}\right]\right|\right) \quad \text { with } f^{\prime}<0 .
$$

While the distance between the former and latter may affect the bargaining duration of disagreement, it would take time for the seller (or buyer) to make an offer equal to the correct reservation price of buyer (or seller). The more uncertain about the reservation price the seller (or buyer), the probability for the seller's offer to be rejected is greater, resulting in a longer bargaining delay.

\section{Conclusion}

This paper has attempted to build a model predicting the bargaining delay and has shown that it importantly depends on the information structure. The methodology used here is first to describe the bargaining procedure as three-state Markov stochastic process based on the fact that offers and counter offers by bargainers of both sides are always in one of three intervals. And since the asymmetric information affects the transitional probabilities which determine the duration for the stochastic process to be in a state, it is shown that the information problem determines the duration of bargaining disagreement. So, the perfect information implies a very short period of bargaining delay or instantaneous agreement while imperfect information does a very long period of bargaining procedure. The implication of two propositions in this paper is very clear and simple in all kind of bargaining problems. For example, the arbitrator in a strike should try to eliminate information asymmetry involved in the bargaining and make the information each side has as perfect as possible. One may extend the argument in this paper to several directions. One of the extension is to the bargaining problem where the selection of proposer is random. Or the other one is the case where there are two types for each player.

\section{References}

[1] Admatti, A,R and M, Perry, Strategic delay in Bargaining, Review of Economic Studies, 54, 2, p.345-364, 1987

DOI: http://dx.doi.org/10.2307/2297563

[2] Binmore, K and Nir Vulcan, "Applying the game thoey to automated Negotiation." Netnomics, 1, 1 p. 1-9, 1999

[3] Crampton, P. C. "Bargaining with Incomplete Information; An Infinite-Horizon Model with Two sided Uncertainty", Review of Economic Studies 51, 4, p. 579-93, 1984.

DOI: http://dx.doi.org/10.2307/2297780

[4] Crampton, P.C. "Strategic Delay in Bargaining with Two-sided Uncertainty" Review of Economic Studies, 59,1 P.205-25, 1992

[5] Crawford, V. "A Theory of Disagreement in Bargaining" Econometrica 50, 1982.

[6] Feinberg, Y and Skrzypacz, A. "Uncertainty about Uncertainty and Delay in Bargaining", Econometrica Vol. 73 No.1 Jan. 2005

DOI: http://dx.doi.org/10.1111/j.1468-0262.2005.00565.x

[7] Fudenberg, D. and Tirole, J., " Sequential Bargaining with Incomplete Information", Review of Economic Studies, 1983.

DOI: http://dx.doi.org/10.2307/2297414

[8] Heckman, James J. and Singer B. "Econometric Duration Analysis", Journal of Econometrics 24, 1984.

[9] Kennan, John. "The Duration of Strikes in U.S. Manufacturing" Journal of Econometrics 1985.

DOI: http://dx.doi.org/10.1016/0304-4076(85)90064-8

[10] Kennan, J. and Robert Wilson, Theories of Bargaining Delay, Science, Sep. 1990,

[11] Manzini, P and Mariotti M., "Going alone together:joint outside option in bilateral negotiations. The Economic Journal, 114, p.943-960 Oct. 2004

[12] Myerson, R. B., "Two-Person Bargaining Problems with Incomplete Information", Econometrica 52, 1984.

[13] Muthoo, Abhinary, A Nontechnical Introduction to Bargaining Theory, World Economics, 1, 2, p.145-66, 2000

[14] Muthoo, Abhinary, Bargaining Theory with Applications, 2002, Cambridge University. 
[15] Osborne, Martin and Rubistein, Ariel, Bargaining and Markets, 1990, Academic Press.

[16] Rubinstein, A., "A Bargaining Model with Incomplete Information about Time Preferences" Econometrica 53, 1985.

[17] Rubinstein, A and Wolinsky, A "Equilibrium in a Market with Sequential Bargaining", Econometrica 53, 1985.

[18] Sobel, J and Takahasgi, I., "A multistage Model of Bargaining", Review of Economic Studies 1983.

DOI: http://dx.doi.org/10.2307/2297673

[19] Sutton, J., "Noncooperative Bargaining Theory: An Introduction" Review of Economic Studies LIII, 1986.

[20 ] Taylor, $\mathrm{H}$ and Samuel Karlin, An Introduction to Stochastic Modelling, 3rd. Academic Press, 1998.

[21] Vidal-Puga, J. J. "Delay in the Alternating - offers model of bargaining", IVIE Working paper, 2008

DOI: http://dx.doi.org/10.1007/s00182-008-0128-3

\section{Chang-kon Choi [Regular member]}

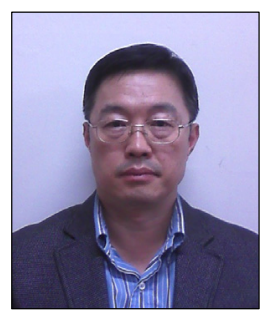

- Aug. 1985 : M.A in Economics Chonbuk National University.

- Dec. 1991 : Ph.D. in Economics The Univ. of Iowa.

- Oct. $1993 \sim$ Current : Professor, Dept. of Economics, Chonbuk National University

$<$ Research Interests $>$

Labor Economics and Macroeconomics 